\title{
a marriage of custom and introduced skills: restorative justice, bougainville style
}

\author{
John Tombot
}

is a traditional chief from Siwai in south-west Bougainville. He was formerly a village court magistrate and in recent years has been involved in the mediation of many conflicts associated with the Bougainville crisis.

\section{Personal and cultural background}

I was born in 1959 in the Siwai District of south-west Bougainville and brought up during the colonial time attending a Catholic school until grade six. When I left school I returned to live with my parents in our village. It was in 1975, the year of Papua New Guinea's independence, that I first became involved in community work, especially with young people. But before I talk about that work, I want to give some background on how people from my area perceive their history.

My father was a paramount chief. He used to solve disputes in our traditional way, or topotopoilu ('wanbel' in our language). When the Australian colonial government established local level councils to govern and administer justice, councillors were elected to this new level of government. Unfortunately my father was illiterate and could not speak Pidgin so his brother was elected. The authority to deal with disputes was taken away from my father and was given to the councillors. This was one of the changes that had happened to us during this time. We still believed then that men could have more than one wife. More wives meant more power, more pigs and more wealth to provide 
feasts. This was our way. Sorcery was a strong cultural practice. In my grandfather's time we did not believe in the Christian God but in a Siwai Creator. My ancestors prayed for their food crops to be productive. Farmers put aside their best food and let it grow rotten so the Creator could smell it and bless us with more food. The first Catholic priest in Siwai was French. He told us not to believe in our gods and our customs. We began to believe in Catholic beliefs. I was brought up thinking about certain things from the distant past and some things from the new ways of thinking.

In 1975 I began working with young people, helping to settle disputes, and learned a lot from the elders. The village elders were pleased with my work and asked me to become a village court magistrate. I remember with joy the celebration and feasting on that day when I became a magistrate in my village. There were, of course, traditional ways of mediating disputes. Here, I will explain how we fixed disputes in years gone by.

This is what my elders told me. Before the whites found us, troubles did not arise that often. We lived in isolation from each other, without a growing population. Movements were restricted. We had to do as we were told. The major sources of conflict in those times were pigs eating from gardens and domestic violence. The chief asked the disputing people to meet and to come to an agreement. When they did, the chief prepared a betel nut with lime and mustard on his thumb and asked them to take their share and chew it. While they chewed, the chief dug a hole and then told the chewing people to spit into the hole. Then he covered the hole. He told them to have courage and shake hands. The anger and hate was now in the covered hole. Many problems were caused by sorcery. Sorcery involved special, mostly secret, things. Special people held these secrets. Magic and sorcery could involve either good or bad things. I mention this because during the Bougainville crisis I dealt with a lot of sorcery. I saw that changes had come about in dealing with sorcery. During the crisis there were many youths who had become powerful because of the war but who were confused about old ways of dealing with sorcery. These 
youths were not sure what they were doing and were causing chaos. I will return to this later.

\section{The Bougainville crisis and justice}

Until the Bougainville crisis I worked as a magistrate and then as a sub clan leader. The 'crisis' began in late 1988. The word crisis is an accurate description. People suffered. Conflict was not resolved in traditional ways, nor in new ways such as through the magistrate and the law. It was dealt with in a mixed up 'crisis' way that was usually not good: fighting, killing, bad things, confusion. Now that the crisis is over, we are trying to mend the mental wounds caused by this confusion. I am going to tell you the following story from the crisis. It will show what things were happening to village people. It will show how the trauma that is now in Bougainville came from that crisis. This is the story of how my family were accused of sorcery during the crisis and how conflict resolution took place during that time.

My uncle was walking home and a young man asked him for a nut and they shared lime from my uncle's container. The youth went to his own village and when he got home he said to his wife that his mouth was on fire. Next morning he went to the haus sick because his mouth was on fire and his wife said, 'That man had put poison in that lime'. The youth died that afternoon. Three weeks after the youth's funeral a man reported my uncle to the rebels, the Bougainville Revolutionary Army (BRA), and they came to my village and arrested my uncle and his wife and took them away. We were all in fear. What were we to do? Torture? Everyone was afraid of the torture that the crisis had brought and the killing of anyone suspected of being a sorcerer, a spy, or a government supporter.

For three days the rebels tortured my uncle and my aunty by hanging them over a fire and beating them in an attempt to make them confess to having poisoned the young man. 'But we are not sorcerers', they said. They became tired and were close to death and could no longer speak. Then the rebels took them down from the rope. A Catholic catechist came to my village and told us: 'They are now about to die'. I went to the rebels' 
camp to try and secure their release. I tried to mediate and the commander said, 'The rebel youths have all the control now. They do not listen. Go now or they will kill you and me.' Then the commander said that if our village gave traditional compensation to the rebels and the dead youth's family, my aunty and uncle might be saved. Our clan paid 500 Kina (PNG currency) and five strings of shell money. When I gave the money to the commander he said, 'I will try and stop the torture now'. Six weeks later the rebels brought the bodies of my uncle and aunty back to our village. The commander had lied.

Later in the crisis front-line BRA soldiers killed the commander. Today we want to settle this matter with the murderers and the ones who made false reports about sorcery. How are we to settle now? What are the ways to clear this thing up? This is the story of only one clan in Bougainville. Many of the problems we face now in my country are from that war. Many of the problems also arise from issues that just come up in life, just as before.

\section{My introduction to conflict resolution}

It was in 1997 that I found some useful ways of solving disputes when I did an advanced course in 'Conflict Resolution Training' with Peace Foundation Melanesia. Later I trained in 'Restorative Justice' with the same organisation.

As participants, we learned that a 'win-win' system of mediation was the most appropriate method of resolving our conflicts. I accepted this 'win-win' approach because it linked with our customary forms of dispute resolution. We went ahead with this system, using some local initiatives to set things up after the course. We performed a series of demonstration workshops in Siwai District. These were successful. People involved in conflicts that had come about in the crisis and which needed attention responded well to this 'win-win' system. Other communities began to request our services.

To date we have facilitated in excess of 300 mediations in the Korikuna area of Siwai, working impartially and without remuneration. The district's Council of Elders has since 
recognised the valuable contribution of mediation to the peace process. It has expressed an interest in formalising the work of mediators in the justice department when all services are eventually restored on Bougainville.

\section{The customary and formal dispute resolution systems}

I fear that if a formal court system returns to Bougainville it might overwhelm our work. Maybe the people will return to the courts in search of large compensation payments, which will only confuse our people. Maybe the mediations in the village will again fall under the control of the court house, the police force and magistrates - those who think they are the only ones who know about justice.

I believe that the court system is unable to deliver justice in Bougainville. The magistrates see themselves as the only ones with power, the only ones who know what justice is. They do not allow the people involved in the dispute to air their views and feelings freely, or to complete what they have to say. They blame the offender or the victim. They make biased decisions. They create further divisions between the two parties and within the community. This system is incapable of bringing peace to Bougainville.

Restorative justice is not a new method in our societies. It is what our ancestors used for thousands of years to resolve minor and major disputes, up until colonial times. During the colonial era all the cases were referred to magistrates. We began to think that the court was an opportunity for earning money. Instead of referring even minor problems to our traditional leaders, who would ask the parties to forgive and reconcile, the people went to the courts. In the courts magistrates would order the offender to pay cash to the victim. That is why we saw going to court as an income-generating activity. This caused an incredible amount of discontent and anger among ordinary people. When the crisis started in Bougainville in 1988, it was a chance to relieve this pent-up hatred and anger. Magistrates were killed and all the disputes that the court had failed to resolve in the eyes of the people were dealt with by burning 
houses, by torture and by murder. Courts and magistrates believed that they were the only ones who knew how to administer justice. I believe that within everyone there is a sense of justice. Every case I mediate proves that ordinary people in the village know what justice is. Restorative justice gives them a way to exercise justice.

\section{A case study of restorative justice}

I will conclude this paper with a short case study of our work as mediators in post-conflict Bougainville. It is an illustration of how we operate. The case concerns a murder accusation against a member of the Resistance Forces. The Resistance were those who fought against the BRA. A Resistance army commander sought the assistance of the mediator to resolve a situation where members of the community were accusing him of shooting and killing a young man who was not involved in the war. The accused was concerned that the allegations were damaging his name and would lead to compensation and retaliation.

The mediators arranged a meeting with the accused and the mother of the dead youth who was leading the accusations. At the meeting the mediators assisted everyone involved to clearly explain their case. After ten hours of discussion it became apparent that the Resistance commander had provided the gun used in the murder. He also revealed the names of the three men who had actually murdered the youth. The meeting ended when the murdered youth's family agreed to pay 10 Kina to mark the settling of the dispute. This small amount of money was acceptable because the victim's supporters accepted that the Resistance Commander did not kill the youth.

We, as mediators, understood that we would have to follow up the accusations against the other people. Three days later the mediators arranged a separate meeting with the offenders' parents, including a few village elders. More people from the same village were in attendance.

First of all we explained to them what the Resistance Commander had said. Then one of them stood up and said: 
Yes we were the ones who killed that boy. We cannot hide anything. We shot him when we were patrolling on the road. It was at about $10.30 \mathrm{pm}$ when we reached their village. That youth was trying to run away after a dog started barking at us. Suddenly I fired at him because we believed he was a BRA soldier, trying to run away in order to get his rifle and shoot us. Their small village was on record as a suspected BRA base.

The meeting ended in the late afternoon, when they suggested a time for mediation. The mediators went to the victim's village to make them aware of the date for the meeting.

On the proposed date we met together and began by welcoming them and encouraging them not to fear any person, just to freely air what they had to say. The victim suggested that the offender should pay siisii, amounting to K50.00, and two strings of shell money each. The offenders said that amount was too little and they wanted to pay K100.00 more 'to settle your cries'. The victims accepted their request and ended the meeting. That was a day when it seemed that the dead boy's body was back with us as we cried and shook hands together.

This is the end of my story. I regret that in the confusion and horror of war we had no real mediation available to save the lives of my aunty and uncle. This illustrates that when systems break down, when there is no will to 'win-win', then there is only chaos and ugliness. Restorative justice is restoring justice to Bougainville and I am grateful for that.

I will now describe the methods used in mediation.

\section{The mediation process}

\section{Step 1. Talking with the Victim(s)}

When a victim(s) requests our services we have a separate meeting with them and their supporters first. We ask them to explain what happened. After that we ask if they want to solve their problems through our process. We explain that we are not judges and they must make the choice. If they agree we then ask them to suggest a suitable time for mediation. We always agree with the time suggested. 


\section{Step 2. Talking with the Offender/s}

On the same, or next, day, we go to see the offenders and their supporters. We inform them what the victims have told us. Almost invariably the offenders will agree with the victims' story. We explain the mediation process to them, as we did with the victims. We ask them to come on the proposed date of the mediation. We also invite the community to come along. If we feel that the anger between the two groups (or individuals) is still very high, we would delay the mediation until they have calmed down.

\section{Step 3. Meeting with both Parties}

When the disputing parties arrive at the meeting house, we begin by congratulating them because of their commitment and by explaining that we are here to solve their problem. We say that we are not judges or magistrates and that our intervention is only the process and that the determination of their problem is theirs.

We then read the Bible text about the Rahep prostitute. The purpose of this text is to draw attention to the following important issues. The first is that those that are free from sin can throw a stone. The second is that we should be willing to forgive many times in order to get a solution.

After that we introduce a few ground rules and ask them to raise some of their own. Then we open the mediation by asking the victims to fully explain their feelings in order that the offenders may understand. We also advise the supporters of the victims that they have to help the victims find a way to a decision that the offenders will be happy with.

Then we ask the offenders to explain carefully why they acted the way they did in order that the victims and the community might understand. 'Do not hide anything', we advise them. We also tell the supporters of the offenders that they must help the offenders to carry their burden. We also invite the other members of the community at the meeting to explain their feelings. 


\section{Step 4. Discussions within each Group}

After that we separate the two parties to discuss among themselves how the problem might be solved. Often this session will last two or three hours or even a whole day. The time required will depend upon the discussions of the parties and the seriousness of the problem.

\section{Step 5. Reaching a Decision with both Parties}

Then we call the parties together to meet and share what they have discussed. First the victims will express what they think the offenders must do to make them happy. Sometimes this will mean replacing what has been broken, returning what has been stolen, providing a feast or compensation with a little cash and/or traditional money.

Most of the time the offenders agree and the mediators ask them how and when they will comply. Often the offenders and their supporters will say that they are ready to comply immediately. The community then shows its support for the decision or agreement.

\section{Step 6. The Act of Reconciliation}

We then ask the victims and offenders to come forward and shake hands and, while this is happening, the mediators will also hold their hands. It is the time to reconcile. While they hold hands the victims will address the offender in words to this effect:

Thank you very much. I'm very glad because you answered my demand. I forgive you from today.

We will try to love each other.

The offenders will thank their victims and promise not to act that way again. They often say:

I recognise my fault and I am very sorry.

Tears will often be shed at this stage. The mediator then takes his/her hands away and the victims and offenders shake hands. 


\section{Step 7. Signing an Agreement}

Finally, the mediator expresses his/her happiness and asks the parties to sign an agreement. The agreement is then sent to the Peace Foundation Melanesia in Arawa for five photocopies to be made for the:

1. Victim;

2. Offender;

3. District's Council of Elders;

4. Provincial Village Court Secretary;

5. Mediator's Supervisor

Step 8. Follow-up

If the offenders do not comply with the agreement, the mediator gives them at least three days to reconsider the matter with their supporters back in their own village.

On the fourth day, the meeting will be reconvened and the mediators will ask the offenders to explain why they have not complied with the agreement. Most of the time they will calm down and agree to comply and end the meeting by shaking hands.

If they still disagree after three meetings, the mediator can then cancel the mediation agreement. 